\section{Effects of Feeding Calcium Salts of Palm Fatty Acids on Lactation and Reproduction Performance in Nili Ravi Buffaloes}

\author{
Hifzulrahman ${ }^{1}$, Muhammad Abdullah ${ }^{1 *}$, Muhammad Uzair Akhtar ${ }^{2}$, Jalees \\ Ahmed Bhatti ${ }^{3}$, Muhammad Saadullah ${ }^{1}$ and Muhammad Naveed-ul-Haque ${ }^{2}$ \\ ${ }^{1}$ Department of Livestock Production, Faculty of Animal Production and Technology, \\ University of Veterinary and Animal Sciences, Lahore \\ ${ }^{2}$ Department of Animal Nutrition, Faculty of Animal Production and Technology, \\ University of Veterinary and Animal Sciences, Lahore \\ ${ }^{3}$ College of Veterinary and Animal Sciences, Jhang, Pakistan
}

\begin{abstract}
A B S T RA C T
The objective of present study was to evaluate the effect of Ca salts of palm fatty acids on milk production, milk fat, plasma metabolites, and reproductive parameters in early-lactating Nili Ravi buffaloes. Sixteen early-lactating Nili Ravi buffaloes received 2 treatments in a completely randomized design with a period length of 120-d. The treatments were 1) $\mathrm{Ctrl}=$ basal diet without supplementation of fat, 2) $\mathrm{Ca}-\mathrm{FA}=$ basal diet with calcium salts of palm fatty acids supplementation. The Ca-FA treatment increased the $3.5 \%$ fat-corrected milk yield by $11.0 \%$ compared with the Ctrl, whereas, the actual milk yield remained unaffected. The Ca-FA treatment increased the concentration of milk fat and milk fat yield by 3.5 and $11.2 \%$, respectively, compared with the Ctrl. However, the Ca-FA treatment did not change the plasma urea nitrogen, glucose, and triglyceride, compared with the Ctrl. Similarly, the reproductive indices were not different between Ca-FA treatment versus Ctrl. In conclusion, the Ca-FA are useful to increase milk production and milk fat yield without effecting the plasma metabolites and reproductive responses in early-lactating buffalo.
\end{abstract}
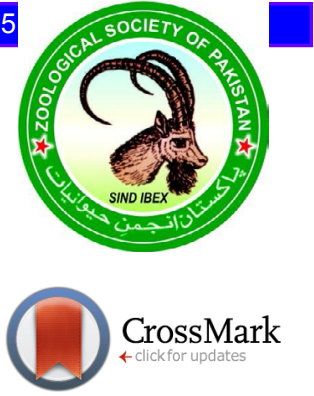

Article Information

Received 25 May 2019

Revised 30 July 2019

Accepted 14 September 2019

Available online 04 May 2020

Authors' Contribution

Hifzulrahman, MA and MNH

designed and conceived the

experiments. Hifzulrahman, JAB

and MS performed the experiment.

Hifzulrahman and MUA analysed

the data. Hifzulrahman and MUA

wrote the manuscript. MNH and MA

reviewed and revised the manuscript.

Key words

Palm fatty acid, Milk yield, Milk fat,

Reproduction, Nili Ravi Buffalo

\section{INTRODUCTION}

A $\mathrm{t}$ the onset of parturition as well as during early lactation, the decrease in dry matter intake is common in dairy animals that could limit the potential to produce milk production because of negative energy balance as suggested by NRC (2001). This period of negative energy balance leads to higher fat mobilization to support lactation production. One of the possible solutions to minimize the effect of negative energy balance is to increase the energy intake during early lactation (McCarthy et al., 2015). Energy intake is most commonly increased by feeding concentrate, based on cereal grains (Bargo et al., 2003), however, slug feeding of starch-based supplements may result in decreased dry matter intake (Auldist et al., 2013) and milk yield (Doyle et al., 2006). Feeding of fats is another possible solution to increase the energy density of a diet. Fat feeding increases energy density and energy intake without the risk of acidosis associated with feeding highly fermentable carbohydrates (Jenkins and McGuire, 2006).

\footnotetext{
Corresponding author: mabdullah@uvas.edu.pk 0030-9923/2020/0005-1637 \$ 9.00/0

Copyright 2020 Zoological Society of Pakistan
}

Vegetable oils are often fed in buffalo and cow diet and contains higher concentration of unsaturated fatty acids (FA) compared with the saturated FA. Negative effect of unsaturated FA was more often observed on dry matter intake, milk production, milk fat, and ruminal fermentation (Jenkins and Jenny, 1989; Pantoja et al., 1996; Rabiee et al., 2012). As a result, many studies (review by Jenkins and McGuire, 2006) were performed to investigate the fat feeding strategy without altering the ruminal fermentation. Two strategies were adopted to achieve this target: 1) protecting unsaturated FA by $\mathrm{Ca}$ salt formation and 2) feeding highly saturated FA.

Most Ca salts products used in dairy cow diet and available in market are derived from palm FA distillate, a by-product of palm oil processing and these products have balance of saturated and unsaturated FA, mainly C16:0 and 18-C FA (Rico et al., 2014). A recent meta-analysis reported a positive effect of $\mathrm{Ca}$ salts of palm FA on production and composition of milk in dairy cows (Rabiee et al., 2012). Fat supplementation increased probability of cows to become pregnant and decreased time to conception and interval to first ovulation during early lactation in dairy cows (de Veth et al., 2009). Other studies also reported improved performance of reproduction on fat feeding, but 
results were inconsistent (Santos et al., 2008).

As per authors' knowledge, few studies evaluated the response of rumen-inert fats on milk production and composition in buffaloes (Polidori et al., 1997; Shelke et $a l ., 2012$ ) and only single study reported the reproductive response of fat feeding in buffalo (Ramteke et al., 2014). Therefore, the fat feeding topic has received so far, less attention for buffalo than for cows and is not much investigated to date. Hence, the current study was planned with the objective to investigate the effects of feeding Ca salts of palm FA on milk production, milk fat, plasma metabolites, and reproductive performance in earlylactating Nili Ravi buffaloes.

\section{MATERIALS AND METHODS}

\section{Animals}

The study was conducted from November 2016 to February 2017 in a tie-stall pen located at the Buffalo Research Institute, Livestock and Dairy Development Department, Punjab $\left(31.02^{\circ} \mathrm{N}, \quad 73.85^{\circ} \mathrm{E}\right.$, and 186 $\mathrm{m}$ altitude; Pattoki, Pakistan). The experiment was performed in accordance with the guidelines by University of Veterinary and Animal Sciences, ethical committee for animal welfare. Sixteen lactating Nili Ravi buffaloes were grouped on the basis of their days in milk (pretrial average days in milk $=18 \pm 8.91$; mean \pm SD) and daily milk yield (pretrial average milk yield $=6.73 \pm 2.49 \mathrm{~kg} / \mathrm{d}$ and milk fat $=5.60 \pm 0.56 \%$; mean \pm SD). All the buffaloes were kept and fed treatment diets in a naturally ventilated barn and water was available to all animals round the clock.

\section{Experimental design, treatments and feedings}

The buffaloes were randomly assigned to two treatment diets in a complete randomized design for the period length of 120-d. The treatments were 1) Ctrl = basal diet without supplementation of fat and 2) Ca$\mathrm{FA}=$ basal diet with supplementation of calcium salts of palm FA (Energizer Gold; IFFCO, Johor, Malaysia). The Ca-FA supplement contained mainly C16:0 (47.0\%), C18:1 (38.0\%), and C18:2 (8.0\%) in FA profile. The CaFA supplement was top-dressed to provide $200 \mathrm{~g}$ of $\mathrm{Ca}$ salts of palm FA/buffalo per day. Diet was composed of oats fodder and wheat straw fed ad-libitum along with a prepared concentrate at the rate of $5 \mathrm{~kg}$ per buffalo per day (Table I). The diets were formulated using Cornell-PennMiner-Dairy 3.0.10 from Cornell University (Ithaca, NY), University of Pennsylvania (Philadelphia, PA) and Miner Institute (Chazy, NY), based on Cornell Net Carbohydrate and Protein System 5.0.2. All the buffaloes were fed as a single herd and feeding time was $0900 \mathrm{~h}$ and frequency was once daily.
Table I. Ingredient and nutrient composition of basal diet.

\begin{tabular}{ll}
\hline Item & Diet \\
\hline Ingredient (\% of DM) & 35.0 \\
Wheat bran & 15.0 \\
Corn gluten feed & 13.0 \\
Sugarcane molasses & 13.0 \\
Corn grain & 10.0 \\
Rapeseed meal & 7.00 \\
Canola meal & 4.00 \\
Soybean meal & 0.50 \\
Calcium carbonate & 2.00 \\
Mineral mixture & 0.50 \\
Salt & \\
Nutrient composition & 86.8 \\
Dry matter (\%) & 19.7 \\
Crude protein (\%) & 28.2 \\
Neutral detergent Fiber (\%) & 43.3 \\
Non-fibrous carbohydrate (\%) & 3.00 \\
Ether extract (\%) & 9.70 \\
Ash (\%) & 2.90 \\
Predicted ME (mcal/kg) &
\end{tabular}

\section{Sampling and analysis}

Buffaloes were milked out by hand milking procedure at 0600 and $1800 \mathrm{~h}$ and milk yield were recorded daily for each buffalo individually (Mor et al., 2018). Samples of milk were collected after each week to analyze percentage of milk fat through Gerber method (ISO, 1976). Feed samples of basal diet was analyzed for proximate analysis according to the procedure given by the AOAC (2005). Blood samples of all buffaloes were collected on monthly basis from jugular vein. Samples after collection in heparinized syringes were immediately centrifuged at $2000 \mathrm{rpm}$ for 15 minutes. Plasma was separated, aliquoted, and stored at $-20^{\circ} \mathrm{C}$ to be assayed by enzymatic method and estimated for the analysis of Glucose (BioMedGlucose L.S, Egy-Chem for lab technology, Badr city, Elrubaki, Egypt), plasma urea nitrogen, and triglyceride (Fluitest Urea and Fluitest TG, respectively, from Analyticon Biotechnologies AG, Litchenfels, Germany). Buffaloes were observed by the same technician for 30 minutes, 2 times daily for signs of estrous, and were artificially inseminated (AI) accordingly. Date and number of services per buffalo was recorded and buffaloes were inseminated even after the trial period of 120-d. Pregnancy 
diagnosis was performed by rectal palpation of the uterus, 60 days post AI. Data of pregnancy diagnosis was recorded after the experimental period up to December 2017 in order to observe the confirm pregnancy status of buffaloes. Reproductive parameters were calculated from the recorded data of AI, number of services per buffalo, and confirm pregnancy status of each buffalo. Projected calving interval was calculated by adding 310 days in days open of each buffalo.

\section{Calculations and statistics}

Data were analyzed using MIXED procedure of SAS University Edition (SAS Institute Inc., Cary, NC). Treatment, treatment week, and their interaction were included as fixed effects. The initial observation in the beginning of experiment of production parameters were used as a covariate to minimize the biasness in the results. Treatment differences were considered significant if $\mathrm{P} \leq$ 0.05 and as a trend for $0.05<\mathrm{P} \leq 0.10$. All the results are presented as least squares means with standard errors of the mean.

\section{RESULTS}

The treatment into weak interaction was nonsignificant in the data for any parameter and therefore it is not presented in the results.

\section{Milk yield and milk composition}

The milk yield and milk composition results are summarized in Table II. The Ca-FA treatment had no effect on milk production compared with the $\mathrm{Ctrl}(\mathrm{P}=$ 0.20), however, the Ca-FA treatment increased the 3.5\% fat-corrected milk production by $11.0 \%$ compared with the Ctrl $(\mathrm{P}=0.04)$. Similarly, the $\mathrm{Ca}-\mathrm{FA}$ treatment increased the concentration of milk fat by $3.5 \%(\mathrm{P}=0.01)$ and milk fat yield by $11.2 \%(\mathrm{P}=0.04)$, compared with the $\mathrm{Ctrl}$.

Table II. Milk yield and milk composition of buffaloes fed treatment diets.

\begin{tabular}{lllll}
\hline Item & Ctrl $^{1}$ & Ca-FA $^{2}$ & SEM & P-value \\
\hline Milk yield, (kg/d) & 8.31 & 8.71 & 0.235 & 0.20 \\
Milk fat, (\%) & 5.68 & 5.88 & 0.051 & 0.01 \\
Milk fat yield, (g/d) & 464 & 516 & 17.8 & 0.04 \\
$3.5 \% \mathrm{FCM}^{3},(\mathrm{~kg} / \mathrm{d})$ & 11.0 & 12.2 & 0.41 & 0.04 \\
\hline
\end{tabular}

${ }^{1} \mathrm{Ctrl}$, basal diet without supplementation of fat; ${ }^{2} \mathrm{Ca}-\mathrm{FA}$, basal diet plus $200 \mathrm{~g} / \mathrm{d}$ calcium salts of palm fatty acid supplementation (Energizer Gold; IFFCO, Johor, Malaysia); ${ }^{3} 3.5 \%$ fat-corrected milk $=0.432 \times$ milk yield $(\mathrm{kg} / \mathrm{d})+16.23 \times$ fat yield $(\mathrm{kg} / \mathrm{d})$.

\section{Plasma metabolites}

Plasma metabolites are presented in Table III. The Ca-FA treatment had no effect on plasma concentration of glucose $(\mathrm{P}=0.61)$, compared with the Ctrl. Similarly, the $\mathrm{Ca}-\mathrm{FA}$ treatment also had no effect on blood urea nitrogen $(\mathrm{P}=0.19)$ and triglyceride $(\mathrm{P}=0.54)$ concentrations, compared with the Ctrl.

Table III. Plasma metabolites of buffaloes fed treatment diets.

\begin{tabular}{lllll}
\hline Item & Ctrl $^{1}$ & Ca-FA $^{2}$ & SEM & P-value \\
\hline Glucose, $(\mathrm{mg} / \mathrm{dL})$ & 92.3 & 91.2 & 1.55 & 0.61 \\
Plasma urea nitrogen, $(\mathrm{mg} / \mathrm{dL})$ & 22.7 & 21.6 & 0.51 & 0.19 \\
Triglyceride, $(\mathrm{mg} / \mathrm{dL})$ & 156 & 159 & 3.5 & 0.54 \\
\hline
\end{tabular}

${ }^{1} \mathrm{Ctrl}$, basal diet without supplementation of fat; ${ }^{2} \mathrm{Ca}-\mathrm{FA}$, basal diet plus $200 \mathrm{~g} / \mathrm{d}$ calcium salts of palm fatty acid supplementation (Energizer Gold; IFFCO, Johor, Malaysia).

\section{Reproductive parameters}

Reproductive parameters are presented in Table IV. The Ca-FA treatment had no effect on calving to first service interval $(\mathrm{P}=0.66)$ and calving to conception interval $(\mathrm{P}=0.60)$, compared with the Ctrl. Similarly, the Ca-FA treatment also had no effect on services per conception $(\mathrm{P}=0.39)$, days open $(\mathrm{P}=0.60)$, and projected calving interval $(\mathrm{P}=0.60)$, compared with the $\mathrm{Ctrl}$.

Table IV. Reproductive performance of buffaloes fed treatment diets.

\begin{tabular}{|c|c|c|c|c|}
\hline Item & Ctrl $^{1}$ & $\mathbf{C a}-\mathbf{F A}^{2}$ & SEM & P-value \\
\hline $\begin{array}{l}\text { Calving-to-first-service interval } \\
\text { (days) }\end{array}$ & 74.5 & 94.4 & 30.39 & 0.66 \\
\hline $\begin{array}{l}\text { Calving-to-conception interval } \\
\text { (days) }\end{array}$ & 169 & 213 & 57.34 & 0.60 \\
\hline Services per conception (no.) & 2.63 & 2.12 & 0.39 & 0.39 \\
\hline Days open (days) & 169 & 213 & 57.34 & 0.60 \\
\hline Projected calving interval (days) & 479 & 523 & 57.33 & 0.60 \\
\hline
\end{tabular}

${ }^{1} \mathrm{Ctrl}$, basal diet without supplementation of fat; ${ }^{2} \mathrm{Ca}-\mathrm{FA}$, basal diet plus $200 \mathrm{~g} / \mathrm{d}$ calcium salts of palm fatty acid supplementation (Energizer Gold; IFFCO, Johor, Malaysia).

\section{DISCUSSION}

In this study, our objective was to evaluate the effects of feeding $\mathrm{Ca}$ salts of palm FA on reproductive responses, milk production and milk composition in early-lactating buffaloes, compared with the control diet. Formation of calcium salts of unsaturated FA was devised to protect unsaturated FA from ruminal biohydrogenation 
(Jenkins and Palmquist, 1984). However, the Ca salt protection of unsaturated FA was incomplete from ruminal biohydrogenation (Wu et al., 1991) due to dissociation of calcium ion within the rumen. Most Ca-salts products used in dairy cow diet and available in market are derived from palm oil processing industry and these products have balance of saturated and unsaturated FA (mainly C16:0 and 18-C FA).

\section{CA-FA supplementation improved production responses}

As expected, the additional intake of energy provided by Ca-FA treatment increased the 3.5\% fat-corrected milk yield, milk fat content, and milk fat yield, compared with the Ctrl, in agreement with the studies conducted on lactating buffaloes (Shelke et al., 2012) and dairy cows (Scott et al., 1995; Batistel et al., 2017). Fat supplementation may spare glucose that could be utilized for the lactose and milk fat synthesis (Rabiee et al., 2012). On the contrary, some studies have observed no effect of fat supplementation on milk yield and milk fat (Rabiee et al., 2012; Polidori et al., 1997; Santillo et al., 2016) in dairy cow and buffalo. We observed $11.0 \%$ increase in $3.5 \%$ fat-corrected milk yield by Ca-FA feeding in agreement with the previous study in buffalo (Polidori et al., 1997), where the increase was 22\% in $4 \%$ fat-corrected milk yield by $300 \mathrm{~g} / \mathrm{d}$ supplementation of Ca salts of palm FA. Higher increase in Polidori et al. (1997) study might be due to higher supplementation level of fat, high crude protein intake in diet and different stage of lactation (Rabiee et al., 2012; Loften et al., 2014). In present study, milk fat content and milk fat yield were also increased by 3.5 and $11.2 \%$, respectively, with Ca-FA feeding, which is also in agreement with the observations of Shelke et al. (2012) and they reported 5.4\% increase in milk fat content in response to rumen protected fat supplementation in buffalo (2.5\% of diet dry matter). Similarly, Batistel et al. (2017) reported 20\% increase in milk fat yield in response to $400 \mathrm{~g} / \mathrm{d}$ supplementation of $\mathrm{Ca}$ salts of palm FA in dairy cow and this higher response also could be due to higher supplementation level of fat feeding compared with the present study. However, Santillo et al. (2016) and Polidori et al. (1997) reported no effect of fat feeding on milk fat content in buffalo. Moreover, Scott et al. (1995) summarized the data of 220 cows from calving until 200 days in milk in response to $450 \mathrm{~g} / \mathrm{d} \mathrm{Ca}$ salts of palm FA addition compared with the control. They reported that fat feeding increased $4 \%$ fat-corrected milk yield and milk fat yield by 8.2 and $10.6 \%$ in multiparous cows and their findings are also in line with the results of current experiment. Increase in milk fat concentration and yield could be due to dietary incorporation of C16:0 into milk fat because mammary gland appears to prefer the dietary $\mathrm{C} 16: 0$ for incorporation into milk fat over other
FA (Hutchinson et al., 2012). The Ca-FA source contained approximately $47 \% \mathrm{C} 16: 0$, which can be incorporated into milk fat and can support the proposed mechanism for increased response.

\section{CA-FA supplementation unaffected reproductive indices}

Calving interval is the key of success in commercial dairy farming. We found no effect of Ca-FA feeding on calving to first service interval, calving to conception interval, services per conception, days open, and projected calving interval in agreement to findings reported by Scott et al. (1995) on summarizing the data of 220 Holstein cows on Ca salts of palm FA supplementation, compared with the Ctrl. Similarly, Hutchinson et al. (2012) fed 51 $\mathrm{g} / \mathrm{d}$ of lipid-encapsulated conjugated linoleic acid in individual cow and reported that this fat supplement had no substantial effect on calving to first service interval, calving to conception interval, and overall pregnancy rate. Contrary to this, Ramteke et al. (2014) observed a significant decrease in postpartum heat days, service period, and No. of AI per conception by feeding of Ca salts of FA in buffalo, compared with the control. Ramteke et al. (2014) fed rumen protected fat by $100 \mathrm{~g} / \mathrm{d}$ 30 days prepartum and $15 \mathrm{~g} / \mathrm{d}$ per $\mathrm{kg}$ of milk yield until 120 days postpartum in buffaloes. Similarly, Tyagi et al. (2010) also reported a decreased service period and AI per conception by $\mathrm{Ca}$ salts of FA supplementation $(2.5 \%$ of diet dry matter), compared with the control group in crossbred cows. It is quite possible that any energy spared by fat supplementation is partitioned toward increased milk production rather than improving the energy status and subsequent reproductive performance of dairy cows (Hutchinson et al., 2012), as observed in the present study by increased fat-corrected milk production and milk fat yield. However, the opposite mechanism proposed in literature for improved reproductive performance by fat supplementation could be: fat feeding increases blood progesterone in ruminants by increasing cholesterol content, which is the precursor of progesterone (Staples et al., 1998). Progesterone, maintain pregnancy and support implantation of the embryo by preparing uterus and it may be due to provision of nourishment to conceptus (Ramteke et al., 2014).

\section{No response of CA-FA feeding on plasma metabolites}

CA-FA feeding did not significantly change plasma glucose and triglyceride level in agreement to findings reported in buffalo (Shelke et al., 2012; Ramteke et al., 2014) and cow (Piantoni et al., 2013), compared with the Ctrl group. No change in glucose level might be due to homeostatic mechanism of body that not allowed significant change in glucose level (Shelke et al., 2012). 
Similarly, Boken et al. (2005) reported no effect of fat supplementation on blood urea nitrogen in agreement to results observed in current experiment.

\section{CONCLUSIONS}

In conclusion, Ca salts of palm FA supplementation increased 3.5\% fat-corrected milk yield, milk fat content, and milk fat yield compared with the control, in earlylactating buffalo in the current study. However, the CaFA feeding had no effect on plasma metabolites and reproductive responses observed in the current experiment, compared with no supplementation. The findings of our study showed that the fat feeding had positive effect on milk production and milk composition without significantly changing the reproductive performance in early-lactating buffalo, which could be due to partitioning of extra energy toward production rather than reproduction.

\section{ACKNOWLEDGMENTS}

We acknowledge the support of Dr. Burhan, Farm Manager, Buffalo Research Institute, Pattoki, Pakistan, and his farm staff for their assistance in this research work. The authors thank the laboratory staff of UVAS for providing support in milk fat analysis and proximate analysis of feed. We also thank Mr. Muhammad Imran, Department of Biochemistry for analysis of plasma. We acknowledge the support of Ghazi Brothers Pvt. Ltd, Lahore, Pakistan for providing the rumen-inert fats used in this research at low price.

\section{Statement of conflict of interest}

The authors declare no conflict of interest.

\section{REFERENCES}

AOAC, 2005. Official methods of analysis. 18th ed. Association of Official Analytical Chemists, Gaithersburg, MD.

Auldist, M.J., Marett, L.C., Greenwood, J.S., Hannah, M., Jacobs, J.L. and Wales, W.J., 2013. Effects of different strategies for feeding supplements on milk production responses in cows grazing a restricted pasture allowance. J. Dairy Sci., 96: 1218-1231. https://doi.org/10.3168/jds.2012-6079

Bargo, F., Muller, L.D., Kolver, E.S. and Delahoy, J.E., 2003. Invited review: Production and digestion of supplemented dairy cows on pasture. J. Dairy Sci., 86: 1-42. https://doi.org/10.3168/jds.S00220302(03)73581-4

Batistel, F., de Souza, J. and Santos, F.A.P., 2017. Corn grain-processing method interacts with calcium salts of palm fatty acids supplementation on milk production and energy balance of early-lactation cows grazing tropical pasture. J. Dairy Sci., 100: 5343-5357. https://doi.org/10.3168/jds.201612503

Boken, S.L., Staples, C.R., Sollenberger, L.E., Jenkins, T.C. and Thatcher, W.W., 2005. Effect of grazing and fat supplementation on production and reproduction of Holstein cows. J. Dairy Sci., 88: 4258-4272. https://doi.org/10.3168/jds.S00220302(05)73112-X

Chilliard, Y., 1993. Dietary fat and adipose tissue metabolism in ruminants, pigs, and rodents: A review. J. Dairy Sci., 76: 3897-38931. https://doi. org/10.3168/jds.S0022-0302(93)77730-9

De Veth, M.J., Bauman, D.E., Koch, W., Mann, G.E., Pfeiffer, A.M. and Butler, W.R., 2009. Efficacy of conjugated linoleic acid for improving reproduction: A multi-study analysis in earlylactation dairy cows. J. Dairy Sci., 92: 2662-2669. https://doi.org/10.3168/jds.2008-1845

Doyle, P.T., Francis, S.A. and Stockdale, C.R., 2006. Associative effects between feeds when concentrate supplements are fed to grazing dairy cows: a review of likely impacts on metabolisable energy supply. Aust. J. agric. Res., 56: 1315-1329. https://doi. org/10.1071/AR05087

Hutchinson, I.A., Hennessy, A.A., Dewhurst, R.J., Evans, A.C.O., Lonergan, P. and Butler, S.T., 2012. The effect of strategic supplementation with trans-10, cis-12 conjugated linoleic acid on the milk production, estrous cycle characteristics, and reproductive performance of lactating dairy cattle. J. Dairy Sci., 95: 2442-2451. https://doi. org/10.3168/jds.2011-4632

ISO, 1976. International Organization for Standardization. Milk-determination of fat content (Butyrometer routine method), ISO 2446, Geneva, Switzerland.

Jenkins, T.C. and Jenny, B.F., 1989. Effect of hydrogenated fat on feed intake, nutrient digestion, and lactation performance of dairy cows. J. Dairy Sci., 72: 2316-2324. https://doi.org/10.3168/jds. S0022-0302(89)79363-2

Jenkins, T.C. and McGuire, M.A., 2006. Major advances in nutrition: Impact on milk composition. J. Dairy Sci., 89: 1302-1310. https://doi.org/10.3168/jds. S0022-0302(06)72198-1

Jenkins, T.C. and Palmquist, D.L., 1984. Effect of fatty acids or calcium soaps on rumen and total nutrient digestibility of dairy rations. J. Dairy Sci., 
67: 978-986. https://doi.org/10.3168/jds.S00220302(84)81396-X

Loften, J.R., Linn, J.G., Drackley, J.K., Jenkins, T.C., Soderholm, C.G. and Kertz, A.F., 2014. Invited review: Palmitic and stearic acid metabolism in lactating dairy cows. J. Dairy Sci., 97: 4661-4674. https://doi.org/10.3168/jds.2014-7919

McCarthy, M.M., Yasui, T., Ryan, C.M., Mechor, G.D. and Overton, T.R., 2015. Performance of earlylactation dairy cows as affected by dietary starch and monensin supplementation. J. Dairy Sci., 98: 3335-3350. https://doi.org/10.3168/jds.2014-8820

Mor, P., Bals, B., Tyagi, A.K., Teymouri, F., Tyagi, N., Kumar, S., Bringi, V. and Vande-Haar, M., 2018. Effect of ammonia fiber expansion on the available energy content of wheat straw fed to lactating cattle and buffalo in India. J. Dairy Sci., 101: 7990-8003. https://doi.org/10.3168/jds.2018-14584

NRC, 2001. Nutrient requirements of dairy cattle, 7th revised edn. National Academy Press, Washington, USA.

Pantoja, J., Firkins, J.L. and Eastridge, M.L., 1996. Fatty acid digestibility and lactation performance by dairy cows fed fats varying in degree of saturation. J. Dairy Sci., 79: 429-437. https://doi.org/10.3168/ jds.S0022-0302(96)76382-8

Piantoni, P., Lock, A.L. and Allen, M.S., 2013. Palmitic acid increased yields of milk and milk fat and nutrient digestibility across production level of lactating cows. J. Dairy Sci., 96: 7143-7154. https:// doi.org/10.3168/jds.2013-6680

Polidori, F., Rossi, C.S., Senatore, E.M., Savoini, G. and Dell'Orto, V., 1997. Effect of recombinant bovine somatotropin and calcium salts of long-chain fatty acids on milk from Italian buffalo. J. Dairy Sci., 80: 2137-2142. https://doi.org/10.3168/jds.S00220302(97)76159-9

Rabiee, A.R., Breinhild, K., Scott, W., Golder, H.M., Block, E. and Lean, I.J., 2012. Effect of fat additions to diets of dairy cattle on milk production and components: A meta-analysis and metaregression. J. Dairy Sci., 95: 3225-3247. https:// doi.org/10.3168/jds.2011-4895

Ramteke, P.V., Patel, D.C., Parnerkar, S., Shankhpal, S.S., Patel, G.R. and Pandey, A., 2014. Effect of bypass fat supplementation during prepartum and postpartum on reproductive performance in buffaloes. Livest. Res. Int., 2: 54-58.

Rico, D.E., Ying, Y. and Harvatine, K.J., 2014. Effect of a high-palmitic acid fat supplement on milk production and apparent total-tract digestibility in high-and low-milk yield dairy cows. J. Dairy Sci., 97: 3739-3751. https://doi.org/10.3168/jds.20137341

Santillo, A., Caroprese, M., Marino, R.O.S.A.R.I.A., Sevi, A. and Albenzio, M., 2016. Quality of buffalo milk as affected by dietary protein level and flaxseed supplementation. J. Dairy Sci., 99: 77257732. https://doi.org/10.3168/jds.2016-11209

Santos, J.E.P., Bilby, T.R., Thatcher, W.W., Staples, C.R. and Silvestre, F.T., 2008. Long chain fatty acids of diet as factors influencing reproduction in cattle. Reprod. Domest. Anim., 43: 23-30. https:// doi.org/10.1111/j.1439-0531.2008.01139.x

Scott, T.A., Shaver, R.D., Zepeda, L., Yandell, B. and Smith, T.R., 1995. Effects of rumen-inert fat on lactation, reproduction, and health of high producing Holstein herds. J. Dairy Sci., 78: 2435-2451. https:// doi.org/10.3168/jds.S0022-0302(95)76872-2

Shelke, S.K., Thakur, S.S. and Amrutkar, S.A., 2012. Effect of feeding protected fat and proteins on milk production, composition and nutrient utilization in Murrah buffaloes (Bubalus bubalis). Anim. Feed Sci. Technol., 171: 98-107. https://doi. org/10.1016/j.anifeedsci.2011.10.003

Staples, C.R., Burke, J.M. and Thatcher, W.W., 1998. Influence of supplemental fats on reproductive tissues and performance of lactating cows. J. Dairy Sci., 81: 856-871. https://doi.org/10.3168/jds. S0022-0302(98)75644-9

Tyagi, N., Thakur, S.S. and Shelke, S.K., 2010. Effect of bypass fat supplementation on productive and reproductive performance in crossbred cows. Trop. Anim. Hlth. Prod., 42: 1749-1755. https://doi. org/10.1007/s11250-010-9631-1

Wu, Z., Ohajuruka, O.A. and Palmquist, D.L., 1991. Ruminal synthesis, biohydrogenation, and digestibility of fatty acids by dairy cows. J. Dairy Sci., 74: 3025-3034. https://doi.org/10.3168/jds. S0022-0302(91)78488-9 